\title{
Testifying the Aquifer Response Under the Stress of Different Scenarios of an Expected Shortage of Surface Water: Case Study South Eastern Nile Delta Fringes, Egypt
}

\author{
Enass A.Elimy ${ }^{1}$ Maha A. Omar ${ }^{1} \quad$ Ahmed A. Hassan ${ }^{2} \quad$ Gamal .Abd EL Nasser ${ }^{1} \quad$ Peter H. Riad ${ }^{2}$ \\ 1.Research Institute for Groundwater. National Water Research Centre, Cairo, Egypt \\ 2.Irrigation and Hydraulics Department, Faculty of Engineering, Ain Shams University, Cairo, Egypt
}

\begin{abstract}
Groundwater is considered one of the important sources in Egypt. However, it is expected to face many challenges in the next few decades. The Eastern Nile delta fringes region, the current area of interest, is one of the most highly developed areas in Egypt for more than three decades. Special attention will be given to the existing large reclamation lands (surface water/groundwater) in the high desert lands and low ones which are adjacent and surrounding the Ismailia canal. Under the expected stress of extensive shortage in surface water of the Nile water system, as a result of the construction of GERD, the rapid population and urbanization, a direct impact on the groundwater system in terms of groundwater levels and water budget will be expected. The main research question of the present study is: what is the response of the Nile Delta Aquifer in the south Eastern Nile Delta Fringes in the case of crisis for the sustainability of existing large projects? Visual MODFLOW was used to simulate the existing condition of the irrigation canals and the expected changes under different scenarios of water shortage. The model was simulated and calibrated for the initial hydrogeological conditions throughout the period (1992-2015). The model was tested for scenarios based on the final calibration as an initial condition. Four scenarios were proposed and simulated for the calibrated regional groundwater model at the study area to evaluate and predict the response of the quaternary aquifer during the decrease of surface water levels for 20 years. These scenarios are: 1 . Decrease of the surface water levels by $10 \%$ against drainage surplus this expression represents the net recharge to the aquifer all the year, 2. Decrease of the surface water levels by $10 \%$ against seasonal drainage surplus for six months (summer, winter), 3 . Decrease of the surface water levels by $20 \%$ against drainage surplus all the year and 4 . Decrease of the surface water levels by $20 \%$ against seasonal drainage surplus for six months (summer, winter). The results of simulated scenarios showed a change and fluctuation in the groundwater levels, while the maximum value of the change in storage was found in scenario 4.in which this value was decreased by $52.9 \%$ between 2017 and 2037. but in all scenarios, the change in storage of the aquifer still stable and continuously increase, by $36.5 \%$ under scenario 2 and $29 \%$ under scenario 4. This volume of storage will be available for pumping by extraction wells in case of surface water reduction.
\end{abstract}

Keywords: Groundwater, Surface water, GERD, water budget, change in storage.

DOI: $10.7176 / \mathrm{CER} / 13-3-04$

Publication date:May $31^{\text {st }} 2021$

\section{Introduction}

In the Eastern Nile Delta region, there are various available water resources. The main source of surface water is Nile water for low lands and large enterprise projects located in high rolling lands (south of Ismailia canal). The average annual flow at Eastern Nile Delta is about 12 billion m3/year. While the other sources of water are groundwater, reuse drainage water, and reuse sewage water. The total potential in the flood plain and the fringes of the Eastern Nile Delta is about 1.5 billion m3/year. It covers an area of about (14,000 km2). (Abdel Salam et al., 2004).In the current paper, special attention is given to the existing large reclamation enterprise projects (groundwater, surface water, and Conjunctive reclamation lands) in Southern East Nile Delta fringes. Many previous studies have focused on the different challenges which are facing Egypt in the recent years of water shortage and its impact on the groundwater levels. El Raway et al, 2021 confirmed that the share of Egypt from Nile water is going to be uninsured as the water demand continuously increases, also many factors increasing this problem such as climate change, the rapid growth of population, and infrastructures in the upstream Nile countries. According to Abdelhalim et al., 2020, the water levels of the groundwater aquifer especially the regional aquifer will be changed as a result of the expected reduction in the surface water and the recharge to these aquifers, due to climate change and the construction of the Grand Ethiopian Renaissance Dam. Aziz et. al., 2019 studied the potential effect of the construction of the GERD on the Nile water in Egypt especially in a pilot area at East delta. These effects included changes in the water level surface or groundwater systems. The paper discussed the effect of decreasing the surface water levels by changing the crop pattern. The paper showed a direct relationship between the surface water and groundwater levels, the study applied a reduction of $50 \%$ to sea water level which leads to a decrease in the groundwater level from $5.0 \mathrm{~m}$ to $2.0 \mathrm{~m}$.then after changing of crop pattern from rice to other crops the level decreased to $1.3 \mathrm{~m}$.finally the paper estimated an undesirable effect of 
GERD on water resources, the salinity of the soil, distribution of crop pattern and the national income. Armanuos, A. M., et al., (2017) used a three-dimensional groundwater model (MODFLOW software) to evaluate the potential impact of Grand Ethiopian Renaissance Dam (GERD). Three scenarios: (1) reduction of water depth in canals, (2) increasing pumping discharge from the aquifer, and (3) combination between the first and second scenarios were simulated. The paper concluded that: the effect of increasing the pumping discharge on groundwater level in the Nile Delta is more significant than decreasing in the water depth of the canals network. The last scenario presents the worst case as the average drawdown reached $1.26 \mathrm{~m}, 1.7 \mathrm{~m}$, and $1.35 \mathrm{~m}$ in western, central, and eastern parts of the Nile Delta respectively. The main objective of the study is to test the operation of the Nile Delta Aquifer in South Eastern Nile Delta fringes by Using MODFLOW to simulate and calibrate the model of the study area for the initial hydrogeological conditions throughout the period (1992-2015). The model was tested for scenarios based on the final calibration as an initial condition. Four scenarios were proposed and simulated for the calibrated regional groundwater model at the study area to evaluate and predict the response of the quaternary aquifer during decreasing surface water levels. Accordingly, a direct impact on the groundwater system will be expected, the model predicted the change in the storage and the groundwater levels for 20 years. these scenarios are summarized as follows: Decrease the surface water levels by $10 \%$ against drainage surplus all the year, Decrease the surface water levels by $10 \%$ against seasonal drainage surplus for six months (summer, winter), Decrease the surface water levels by $20 \%$ against drainage surplus all the year and Decrease the surface water levels by $20 \%$ against seasonal drainage surplus for six months.

\section{Problem definition}

The Eastern Nile delta region is considered one of the important regions in Egypt for land agricultural reclamation projects especially the southern part of the eastern delta fringes. at the high lands where extensive reclamation of the desert area was carried. The area has changed drastically in the last 30 years. Since 1980, the area of the South-Eastern Nile delta has changed as a result of extensive reclamation of desert areas and relatively large scale projects cultivated with surface water from the Ismailia Canal. In addition to the private farms surrounding the Ismailia Canal and other areas irrigated conjunctively (Abdel Salam et al., 2004). South eastern Nile delta fringes especially will be selected to be the study area. Special attention is given to the large reclamation enterprise projects (groundwater-surface water reclamation lands) in the high lands and low lands adjacent to the desert areas surrounding Ismailia canal where large reclamation projects are existing. Under the stress of shortage of Nile water flow and its surface water system into Nile Delta as regional and Eastern Nile Delta as subregional, as a result of the construction of GERD, the rapid population and urbanization Accordingly, a direct impact on the groundwater levels and budget will be expected.

\section{Materials and Methods}

3-1 Study area

The study area covers part of the eastern Nile delta between $31^{\circ} 00^{\prime} \mathrm{E}$ and $32^{\circ} 00^{\prime}$ E longitude and $30^{\circ} 00^{\prime} \mathrm{N}$ and $30^{\circ} 31^{\prime} \mathrm{N}$ Latitude Figure 1. East of the Damietta branch, it occupies part of flood plain at the North West direction .the another portion of the study area occupies by high land desert area located north and south Ismailia canal. The southern part of the study area is bounded by the quaternary aquifer boundary. The study area is characterized by arid to semi-arid climatic conditions. The climate is dry, hot, and rainless in the summer. But it is mild with some precipitations in the winter with mean monthly temperature ranges from about $12^{\circ} \mathrm{c}$ in winter to $27^{\circ} \mathrm{C}$ in summer. the intensity of evaporation is higher in summer than in winter these values were recorded at EL Salhiya station as maximum and minimum values in summer (June) and in winter (December) (9.4 and 3.4 $\mathrm{mm} /$ day/month) respectively (Ismail,2007). Rainfalls are recorded between $(7.2 \mathrm{~mm} /$ day to zero $\mathrm{mm} /$ day) where the maximum values are recorded in January and the zero values recorded in summer months. Higher humidity is recorded in winter than in summer (Dahab et.al, 2009). 


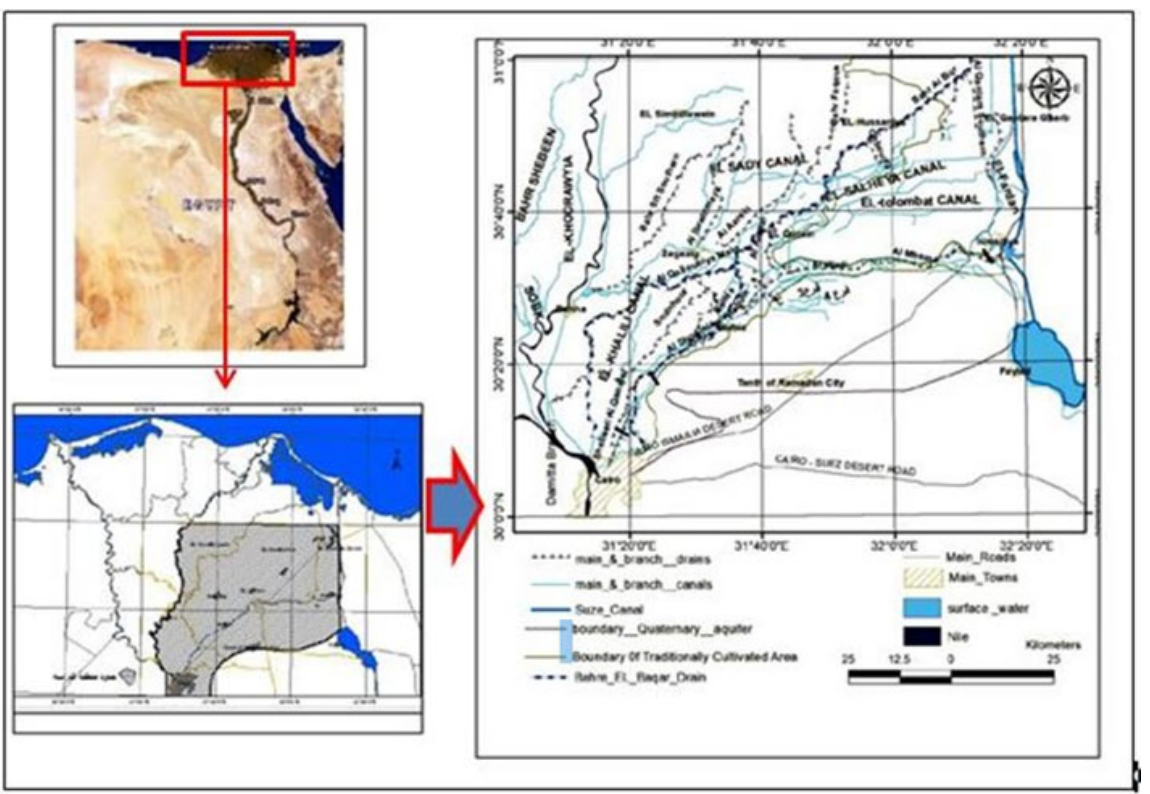

Figure 1. Base map of the study area

\section{3-2 Conceptual Model}

To simulate the present and future condition of the groundwater system in the old land and new reclamation areas existing in the Eastern Nile Delta fringes .a simulation package of visual modflow has been selected. It's popular and easy to use the software in the environment of groundwater modeling for three-dimensional groundwater flow and also contaminant transport simulation. With a USGS code MODFLOW (Harbaugh et al., 2000) with the solver (WHS) for solving the flow and solute transport equations in linear and non-linear systems. The groundwater flow model solves the equation of the groundwater flow by using the method of finitedifference, to build the groundwater model the flow system was divided into a grid of cells. at a single point called a node which is found for each cell, the head value is calculated. (McDonald and Harbaugh, 1988).

3-2-1 Input Data

The conceptual model has been built by representing all the available data concerning the groundwater flow and solute transport model such as the model extension, boundary conditions, hydraulic parameters, recharge rate of agricultural areas in old land and new reclamation areas, and abstraction of groundwater wells.

3-2-2 Model Grid Geometry

The model area covers the southern part of the Eastern Nile Delta fringes including part of the traditionally cultivated lands and the high land areas, bounded by the Damietta branch from the west and Suez Canal from the East as shown in Figure 1. The simulated area covers $16021 \mathrm{~km} 2$ and $143.265 \mathrm{~km}$ in the X-direction and 111.828 $\mathrm{km}$ in the Y-direction as shown in Figure 2. The model area was simulated as a grid mesh with 112 rows and 143 columns consisting of two layers with an average of $700 \mathrm{~m}$ depth. 


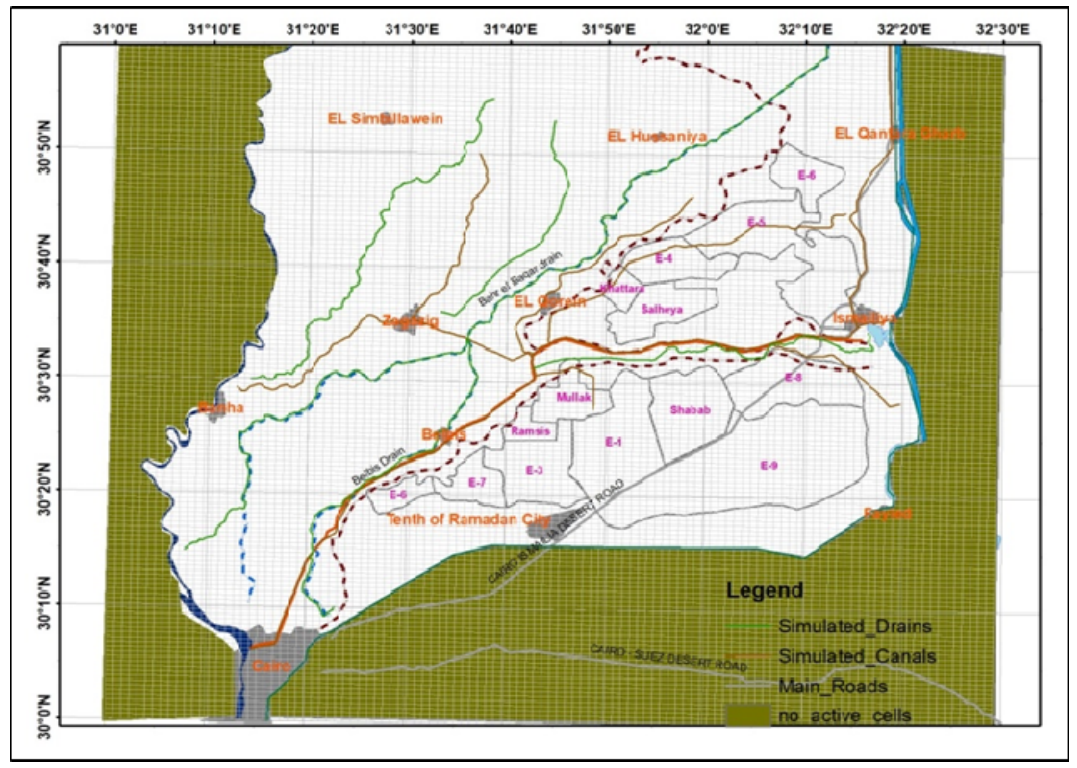

Figure 2. Plan view for the model grid

3-2-3 Input layers for the model

All the main inputs required for the construction of the numerical model are listed here. The visual modflow package requires five kinds of input data. The first needed data is the topographic and base elevations of the model layers, second step is assigning the boundary conditions to the study area, third step is dealing with the data of hydraulic parameters of the main aquifer and the semi-pervious layer, fourth is the groundwater abstraction rates. and fifth is the data related to the recharge of groundwater from the top surface.

Topography:

The topographic elevations of the top layer of the model were extracted from the data of the digital elevation model for Eastern Nile Delta (DEM) was downloaded from the USGS website https://earthexplorer.usgs.gov/ with spatial resolution. with cell size (30m x 30m).by the help of (Arc GIS) software, the raster layer of the top elevations were extracted and exported as an Ascii file ( $\mathrm{x}, \mathrm{y}, \mathrm{z})$ data after converting the coordinate system to the model coordinates, also the data available from topographic contour maps of Eastern Nile Delta Regionally the ground elevations of Eastern Delta ranges between 0 at the north up to 600 meters south eastern direction. While the levels of the upper layer at the active model area ranges between 0 and $200 \mathrm{~m}$ Figure 3 . Presents a topographic contour map of the study area simulated by the model.

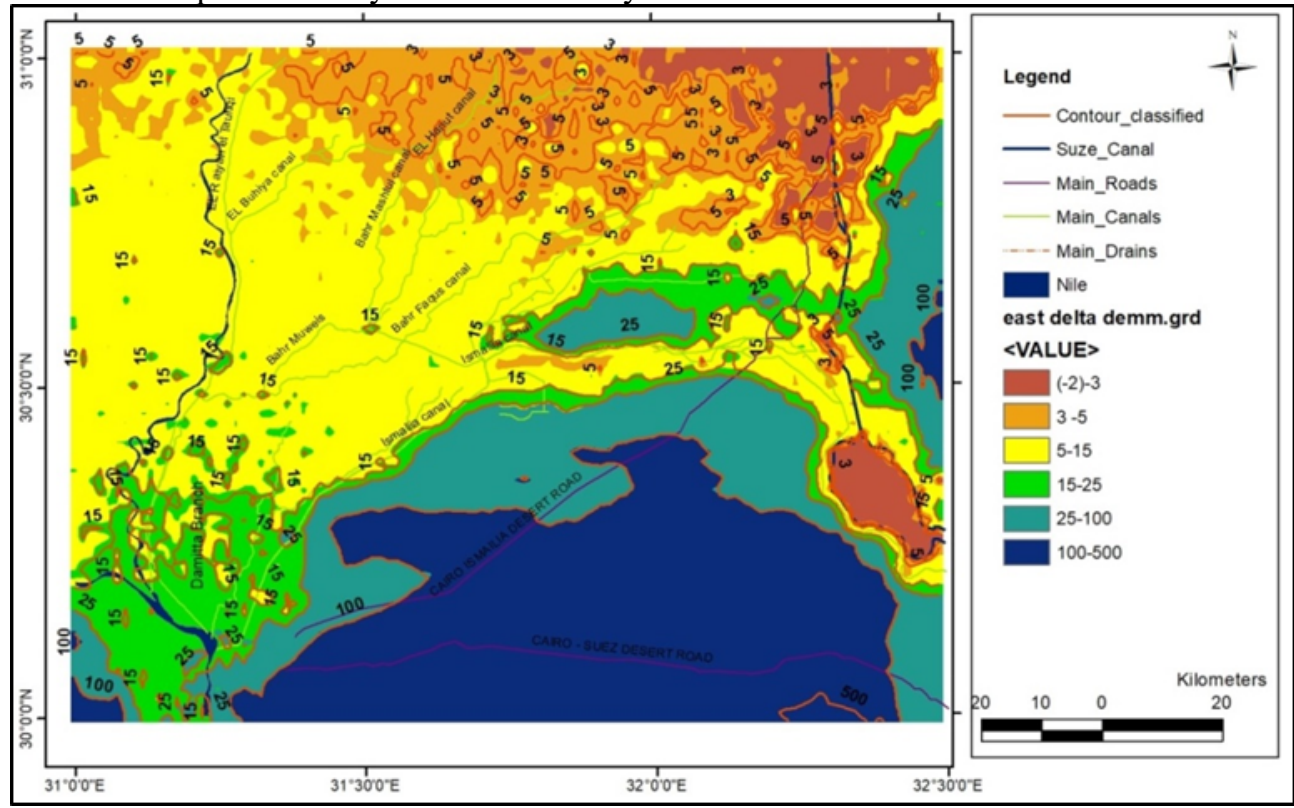

Figure 3. Topographic contour map of the study area

Base Elevations of model layers:

The area of the groundwater model was divided into two main layers related to Nile Delta Aquifer System hydrogeological conditions. 


\section{The first layer (clay cap)}

Represented by the semi-pervious clay layer. This layer overlaying parts of the model area and absent in the other areas. The data corresponding to the base and thickness of the semi-pervious layer were interpolated based on previous studies of (RIGW). Figure 4. showing the simulated thickness of the semi-pervious layer.

The second layer (Quaternary aquifer)

This layer is represented by the Nile Delta aquifer which is considered the main aquifer in the study area. It covers all the area with thickness ranges between $100 \mathrm{~m}$ (south of Ismailia desert road) to $700 \mathrm{~m}$ at the north of the study area as shown in figure 5.

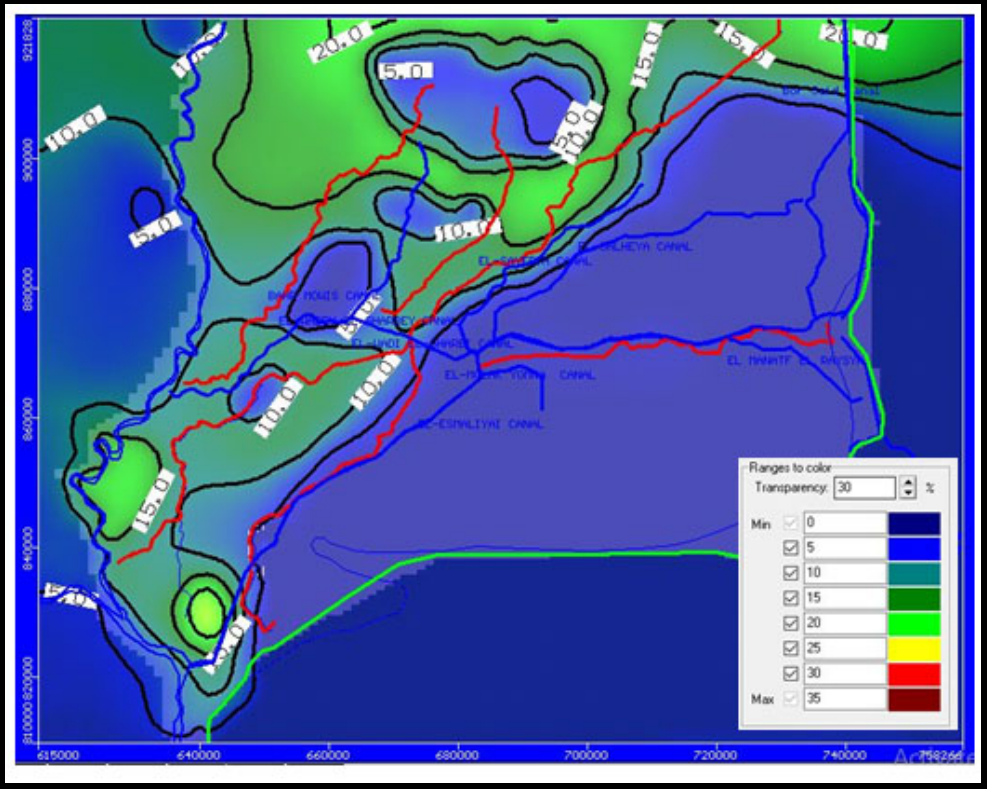

Figure 4. The simulated thickness of the semi-pervious layer. (Output of Modflow).

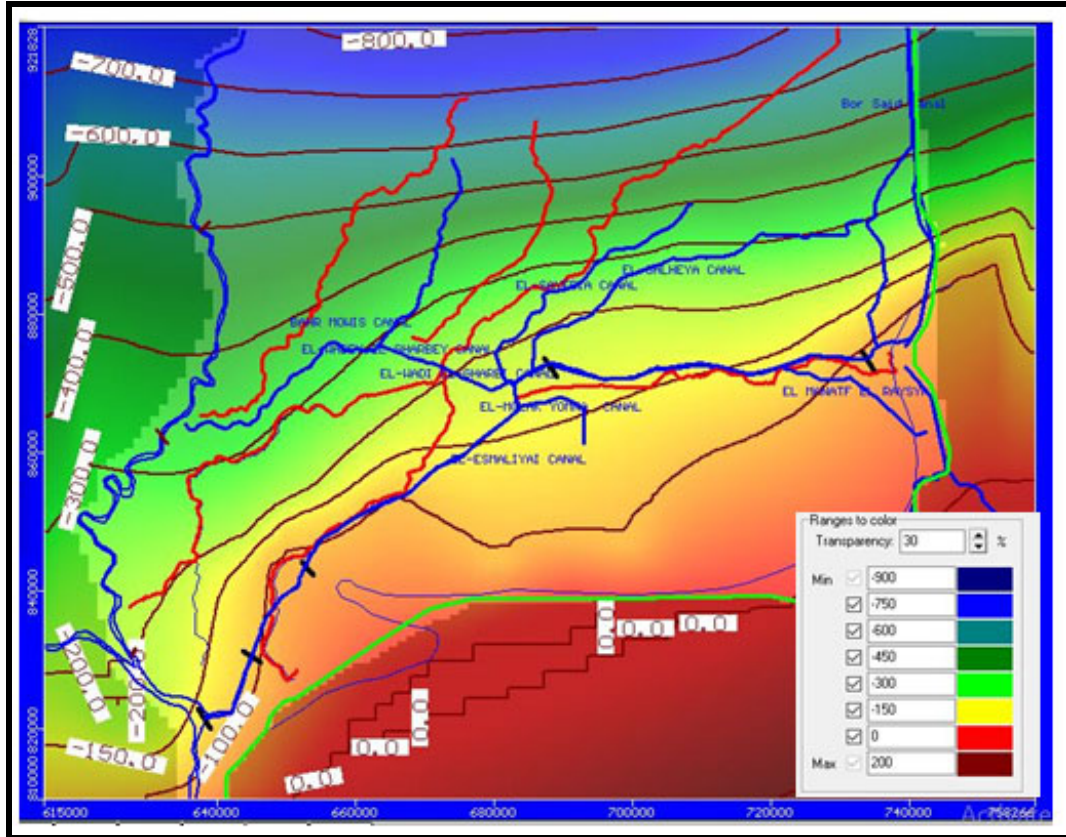

Figure 5. The simulated base of quaternary aquifer layer. (Output of Modflow)

\section{3-2-4 Boundary Conditions}

In the model study area, there were two kinds of boundary conditions (no-flow boundary condition -constant head boundary condition) assigned to the model. The boundaries were defined as follows Figure 6 .

The Southern boundary

The southern boundary is divided into two parts, section (A-B) assigned at the piezometric contour line $+14 \mathrm{~m}$ above MSL and assigned as a constant head boundary. and The southern boundary section B-C coincides with the southern boundary of the quaternary aquifer along the natural fault and therefore considered a no-flow 
boundary (RIGW/IWAC, 1988).

The Eastern boundary

The Eastern boundary represents section (C-D) this section is assigned with a piezometric head which has values of a hydraulic gradient from $+1 \mathrm{~m}$ to $+0.5 \mathrm{~m}$ above MSL.

The Northern boundary

The Northern boundary, section (D-F) assigned with a piezometric head which has values change from $+0.5 \mathrm{~m}$ to $+3 \mathrm{~m}$ above MSL.

The Western boundary

Section (A-F) is assigned with the constant head with a piezometric head which has values change from $+14 \mathrm{~m}$ to $+3 \mathrm{~m}$ above MSL.

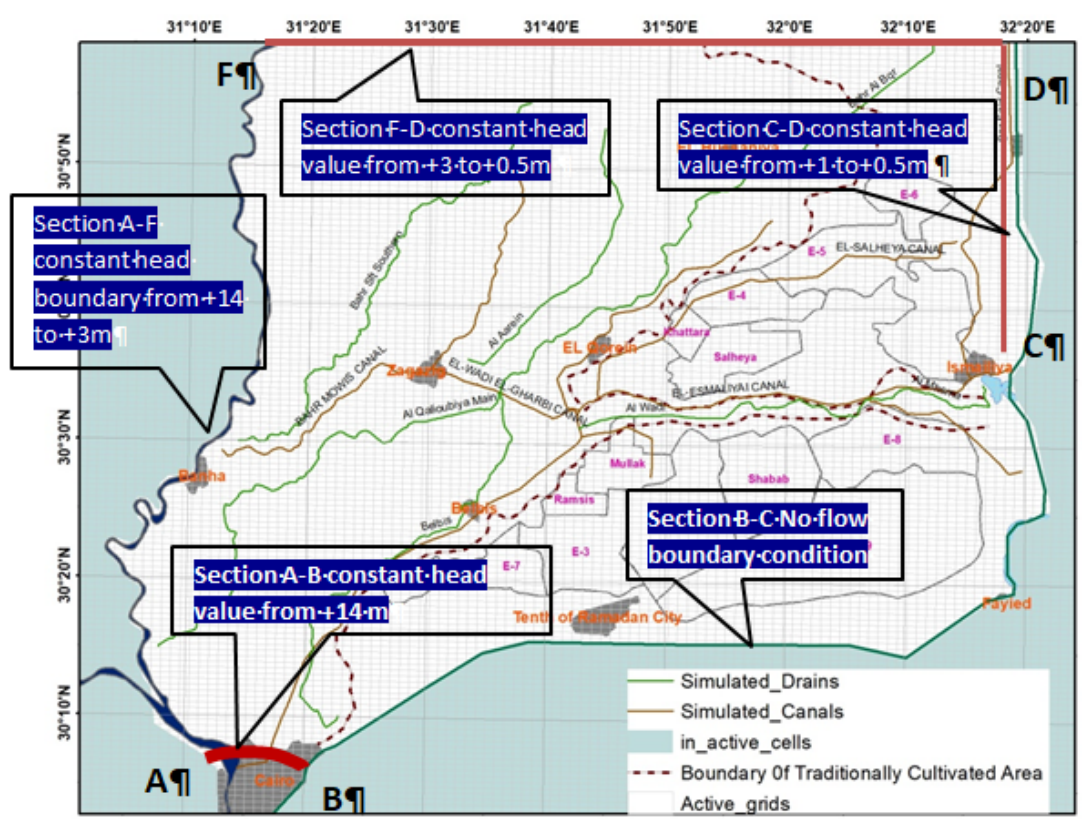

Figure 6. Boundary condition as simulated to the model

\section{3-2-5 Model hydraulic parameters}

The values of hydraulic conductivities were assigned to the model according to many previous studies conducted in the Eastern Nile Delta region (RIGW/IWACO, 1988 and EL Trabily et al 2017 and other previous studies). The values of hydraulic conductivities were assigned to the model for the two simulated layers (clay cap, fine sand aquifer).for the first layer (clay cap) which covers all the old cultivated lands has assigned with a horizontal hydraulic conductivity of value $0.01 \mathrm{~m}$ /day and hydraulic conductive of value $0.25 \mathrm{~m}$ /day with anisotropy factor of 25.in the high lands where the sand hills exist, to simulate this area, the values of vertical hydraulic conductivity will be increased. For the second layer, the hydraulic conductivity in large parts of the study area was assigned as $75 \mathrm{~m} /$ day. These values represent the first assumption for the calibration processes. The Specific yield (Sy) this value was simulated in the study area as $20 \%$ where this value represented as a percentage of the total volume of the saturated aquifer that can be drained by gravity. Values of $\mathrm{S}_{\mathrm{y}}$ for sand and gravel are in the range of 20-35\% (Raghunath, 1992). Specific storage (Ss) this value was assigned to an unconfined aquifer defined as the amount of water released from or taken into storage per unit saturated porous medium and per unit change in the hydraulic head (Raghunath, 1992).

3-3 The interaction between the groundwater and the surface water

Many previous studies have been concluded that at the Eastern Nile delta there is a direct hydraulic interaction between the water courses and the aquifer system. The aquifer is mainly recharged from different water courses existing in the model area as (Damietta branch, Ismailia canal, El Rayah El Tawfiqy, El Saidiya Canal, Mullak canal, EL Qalubiya drain, Belbis drain, and Bahr EL Baqr drain). To study the interaction between the groundwater and the surface water, the previous water bodies were simulated in the model. The amount of seepage to or from the water courses is controlled by many parameters such as (water level, bed level, and conductance). as river package for Damietta branch and canalsthe Damietta branch assigned as river backage but the constant head assigned across the groundwater levels passing through the Nile, while drain package for simulated drains). For Damietta branch, monthly water levels and bottom levels were assigned based on the water levels data upstream and downstream the three barrage along the Nile as (Delta, Banha, Zefta barrage) and the main canals according to (Mowafy,2001) and other previous studies. 
Groundwater Recharge

Recharge is considered one of the important input data to the top system of the model which reflects the mathematical interaction between the piezometric head of the aquifer and the groundwater in the top layer of the model. In the model area, the aquifer is recharged mainly through deep percolation resulting from excess drainage water under agricultural lands. The data of recharge were assigned to the model are based on previous studies from RIGW also by the data extracted from the land use maps for years (1992-2015) at the study area according to Elimy. A.E, et. al,2020, theses maps were generated, also the irrigated area for each reclamation land were estimated for the year 1992,2002, and 2015. The recharge was entered into the model by assigning the value of the net recharge for each area to simulate the steady state condition which started from 1992 then simulation of the transient state to 2015 by assigning the new areas of year2002 and 2015 to reflect the impact of the land use change on the groundwater aquifer.

\section{3-4 Groundwater Discharge}

The groundwater abstraction was implemented to the model by assigning the (locations $\mathrm{x}-\mathrm{y}$, abstraction, well depth) to the cells of the model. The data of previous inventories and field data were collected and analyzed by RIGW (Research Institute for Groundwater) for the year 1992 and 2015 were used in the model the discharge was assigned by production wells distributed over the traditionally cultivated lands and new reclamation areas. Based on RIGW, 1992.

\section{3-5 Model Calibration}

\section{Calibration of steady state}

The model was calibrated in the steady-state condition against the piezometric head contour map for the year 1992 number of (15) observation wells of RIGW were used for calibration processes by trial and error were done to match the between the observed piezometric map and the calculated map by adjusting the values of hydraulic parameters and recharge to get a satisfactory result for the calibration Figure 7 . Shows a graph between the calculated and observed heads.

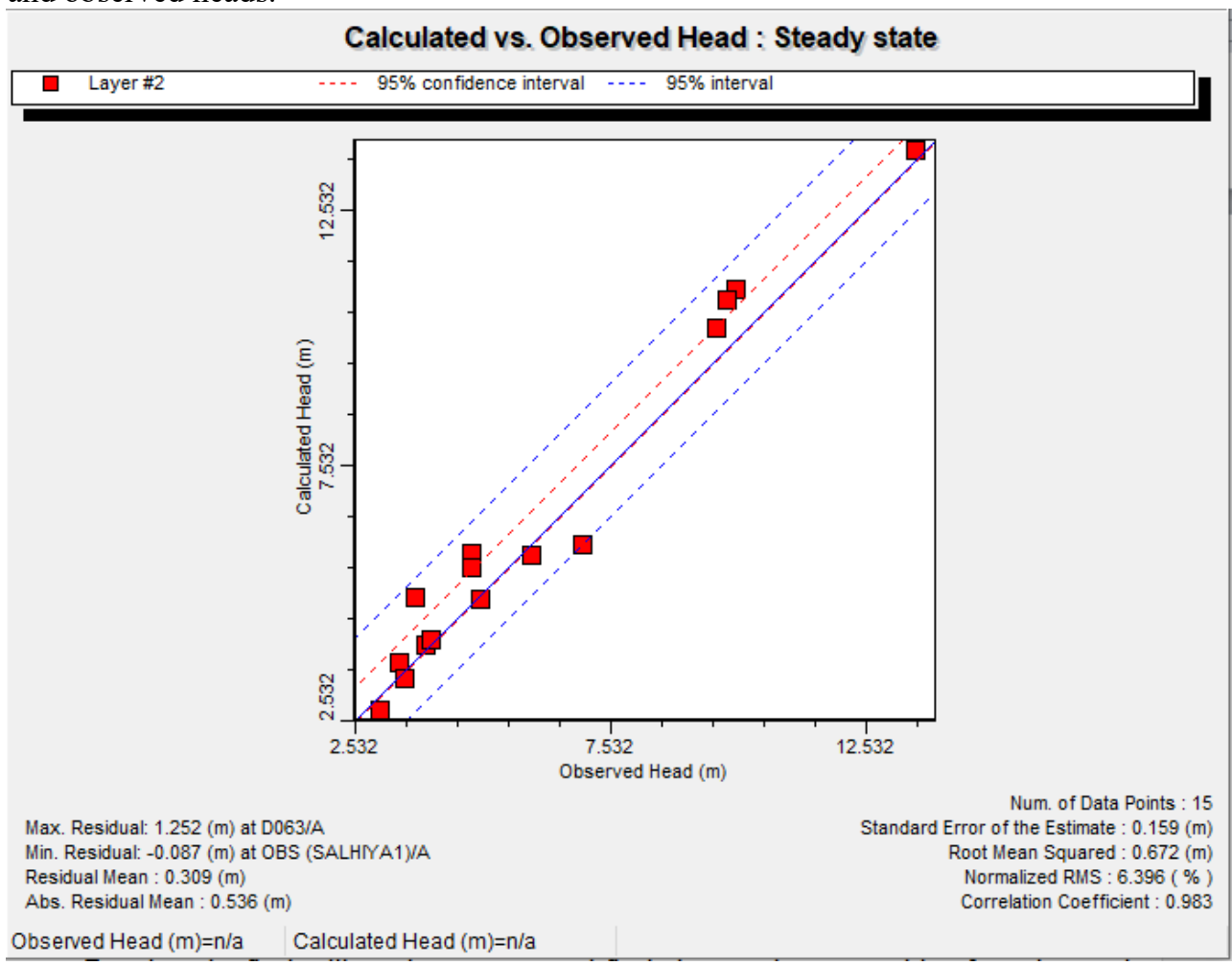

Figure (7).calculated versus observed values of observation wells

Calibration of Transient State

Based on the final calibrated parameters and final piezometric map resulting from the steady state calibration for the year 1992. the model was calibrated for the year 2015. Verification for the model was done against the available piezometric head data for the period from 1992-2015 and the available piezometric head contour map for the year 2015 from RIGW Database. All the boundary conditions and hydraulic parameters were kept constant during the calibration except the extraction and the net recharge distribution. Based on the different inventories in Eastern Nile Delta Region also the recharge values were increased due to the increase of 
reclamation areas with surface or conjunctive use, in the Eastern Nile Delta fringes. The change in reclaimed areas was simulated for the year 2002 and 2015 as mentioned before according to the land use change maps produced by Elimy. A.E et al., 2020.

\section{4-Model Results and Discussion}

The numerical model was calibrated for two conditions the steady state in 1992 and the transient state in 2015. The main output components for the model calibration represented by the water balance of the aquifer and the groundwater levels.

From the calibration for the year 2015, Figure 8 . Shows the cumulative change in storage for the quaternary aquifer

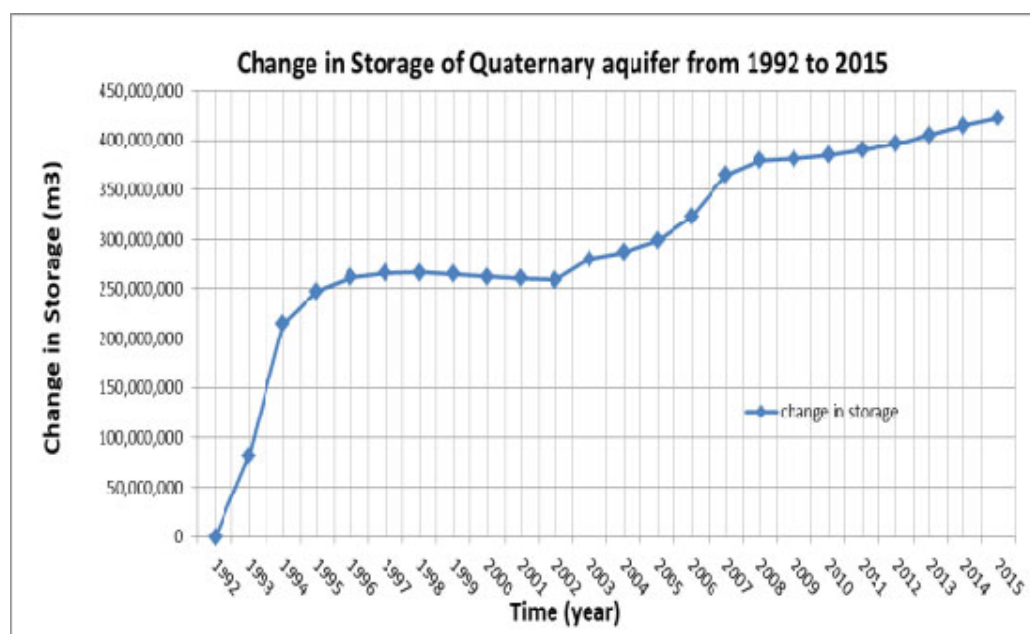

Figure 8. Cumulative Volume of change of Storage for Quaternary Aquifer (m3) from the Year 1992 to 2015 Groundwater levels

The groundwater levels were adjusted and calibrated in the steady and transient state of the model for the year 1992 and 2015. Figure 9. and Figure 10. Show the calibrated piezometric Head Contour Map for steady state 1992 and transient state 2015.

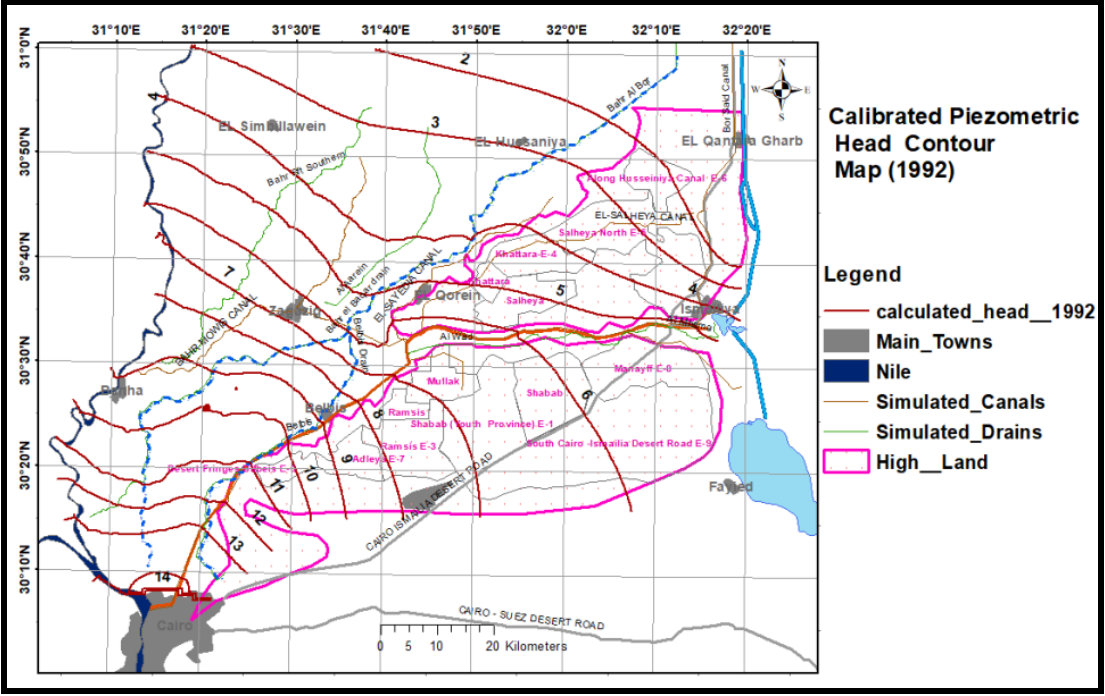

Figure 9. Calibrated piezometric Head Contour Map (1992) 


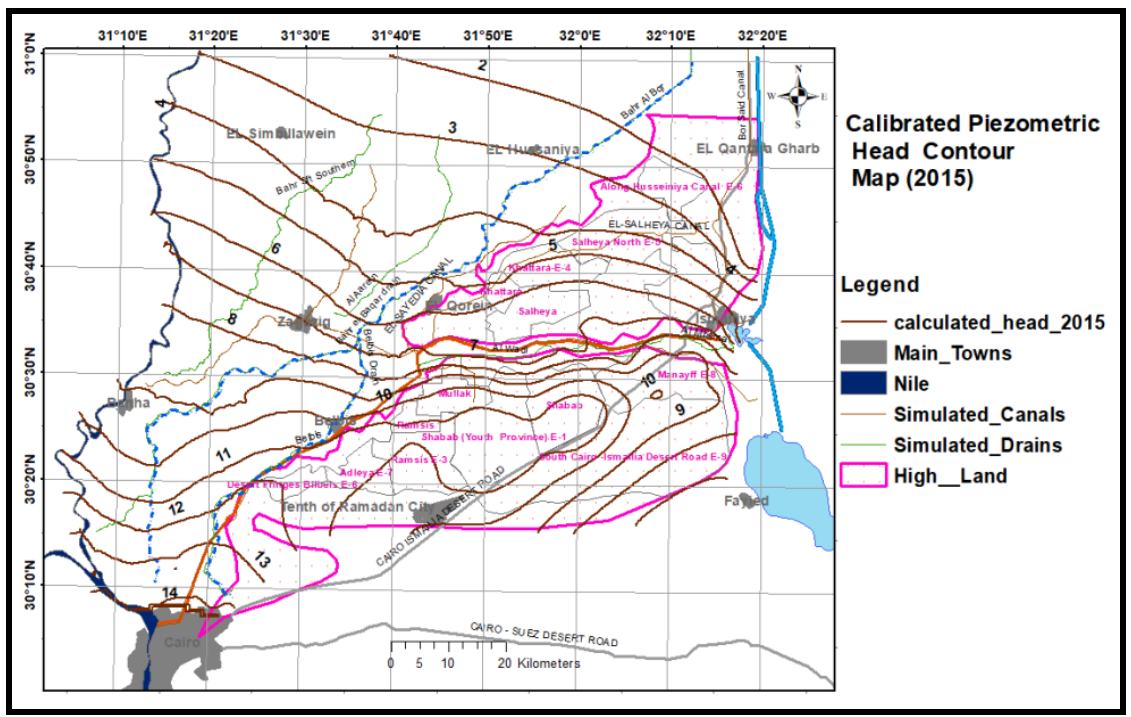

Figure 10. Calibrated piezometric Head Contour Map (2015)

\section{5- Simulated Scenarios}

Four scenarios were proposed and simulated for the calibrated regional groundwater model at the south eastern Nile delta region to evaluate and predict the response of the quaternary aquifer during decreasing the surface water levels under the expected stress of extensive shortage in surface water of the Nile water system, as result of the construction of GERD, the rapid population and urbanization. direct impact on the groundwater system will be expected, the model predicted the change in the storage and the groundwater levels for 20 years. these scenarios are summarized as follows: 1 . Decrease of the surface water levels by $10 \%$ against drainage surplus all the year this mean that the value of net recharge was simulated as constant value to each time step (one year) for each reclamation area, 2. Decrease of the surface water levels by $10 \%$ against seasonal drainage surplus for six months (summer, winter this mean that the value of net recharge was simulated as a different value to each time step (six months) in summer is higher than in winter by a percentage equal to the percentage of water requirement in summer to in winter for each reclamation area, 3. Decrease of the surface water levels by $20 \%$ against drainage surplus all the year and 4 . Decrease of the surface water levels by $20 \%$ against seasonal drainage surplus for six months (summer, winter).

Scenario 1: surface water reduction by $10 \%$ against drainage surplus all the year

Groundwater Levels

To indicate the impact of proposed scenarios on the groundwater aquifer in the study area, some locations at the High land reclamation projects (khattara, Salhiya, Mullak, and El Shabab) existed in the south eastern Nile delta region were chosen to represent the change in the groundwater levels at these areas after 10, 20 years. For scenario (1) as a result of decreasing the recharge from surface water to the aquifer. Figure11. it can be observed that the calculated water levels at each of El Mullak and El Shabab were $10 \mathrm{~m}$ and $9.8 \mathrm{~m}$ at the year 2016 before applying the reduction then the levels decreased to $9.86 \mathrm{~m}$ and $9.45 \mathrm{~m}$ at the year 2017 after that the levels were changed to reach $8.98 \mathrm{~m}$ and $10.12 \mathrm{~m}$ after 10 years, $9.24 \mathrm{~m}$ and $10.42 \mathrm{~m}$ respectively after 20 years. the calculated water levels at each of khattara and El Salhiya were $5.4 \mathrm{~m}$ and $6.9 \mathrm{~m}$ in the year 2017 , after that the levels slightly increased to reach $5.7 \mathrm{~m}$ and $7.2 \mathrm{~m}$ after 10 years, $7.4 \mathrm{~m}$ and $5.9 \mathrm{~m}$ respectively after 20 years. 


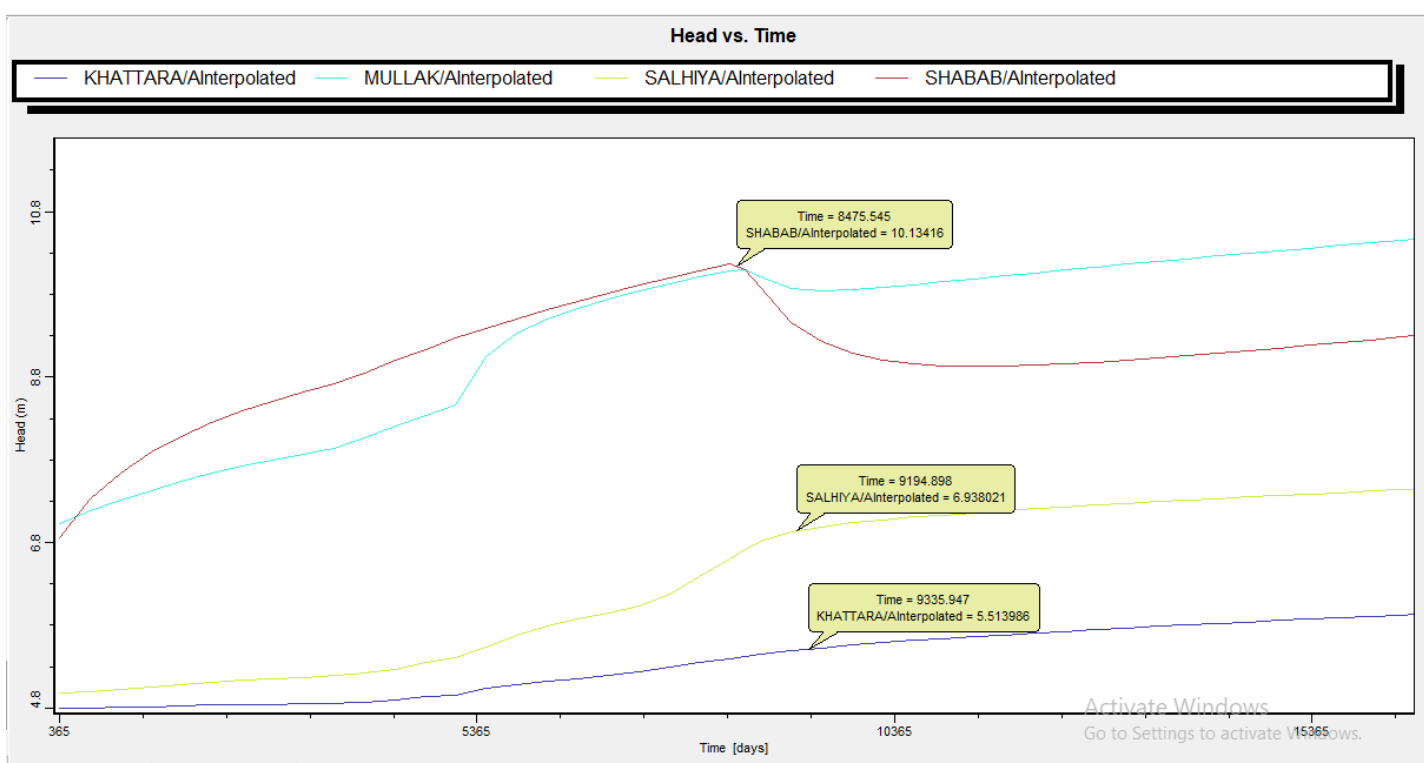

Figure 11. Fluctuation of the groundwater levels after applied scenario 1till the year 2037.

\section{Change in Storage}

In this scenario, the storage in value was decreased from 340,953,800 m3 in 2017 to $298,591,900 \mathrm{~m} 3$ in 2018 after one year of the reduction. Then the value of change in storage increased continuously to reach $333,904,920$ m3 in 2037 as shown in Figure 12.

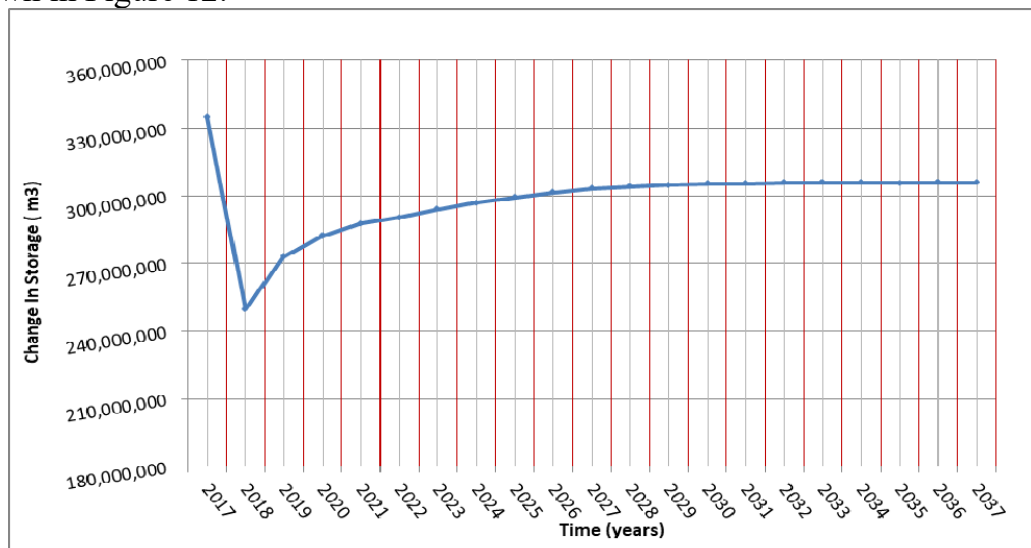

Figure 12. Change in storage (m3) after applied scenario 1 till the year 2037.

Scenario 2: surface water reduction by $10 \%$ against seasonal drainage surplus for six months (summer, winter). Groundwater Levels

For scenario (2) from the results of water levels at different time step Figure13. It can be observed that the calculated water levels at each of El Mullak and El Shabab were $10.32 \mathrm{~m}$ and $9.88 \mathrm{~m}$ at the year 2016 before applying the reduction then the levels increased to $9.86 \mathrm{~m}$ at El Mullak while dropped to $9.45 \mathrm{~m}$ at the year 2017 . at El Shabab the levels decreased to $9.46 \mathrm{~m}$ in the year 2017. the levels were changed to reach $9.65 \mathrm{~m}$ and $8.51 \mathrm{~m}$ after 10 years, $9.85 \mathrm{~m}$ and $8.5 \mathrm{~m}$ after 20 years at El Mullak and El Shabab respectively. the calculated water levels at each of khattara and El Salhiya were $5.49 \mathrm{~m}$ and $6.92 \mathrm{~m}$ in the year 2017 then the levels changed to reach $5.43 \mathrm{~m}$ and $6.37 \mathrm{~m}$ after 10 years, $5.54 \mathrm{~m}$ and $6.62 \mathrm{~m}$ respectively after 20 years. It can be noticed that there is a fluctuation of the water levels appeared as a result of the seasonal recharge rate. 


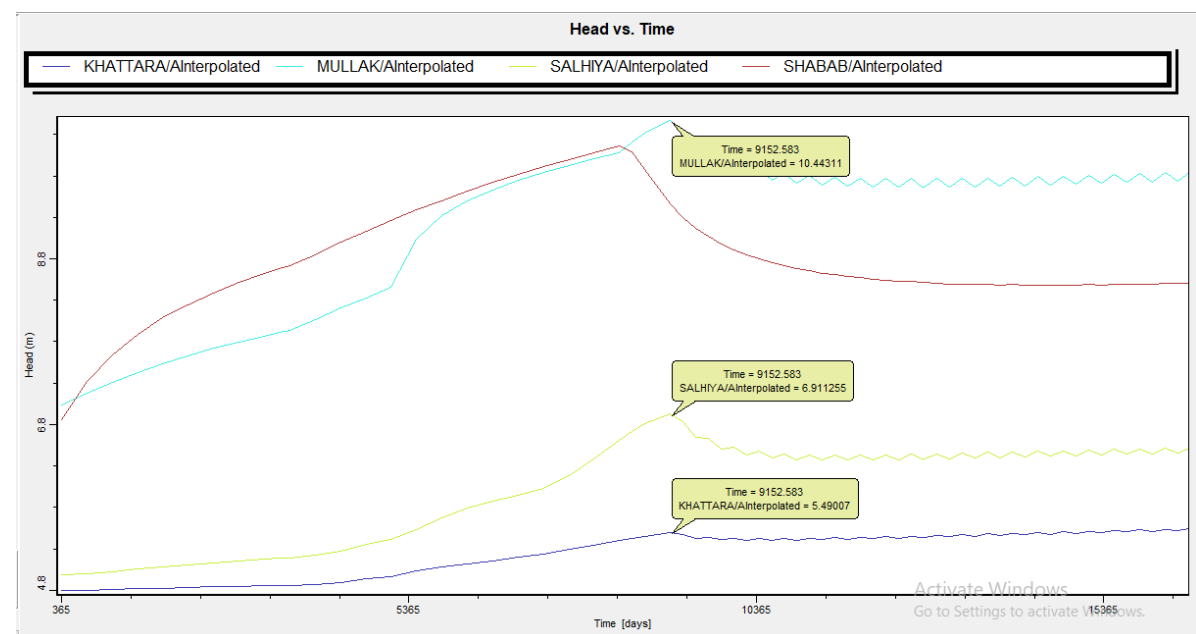

Figure 13. Fluctuation of the groundwater levels after applied scenario 2 till the year 2037 .

Change in Storage

In this scenario, the change in storage value was decreased from $366,689,950 \mathrm{~m} 3$ in 2017 to $44,989,900 \mathrm{~m} 3 \mathrm{in}$ 2018 after one year of the reduction. Then this value increased to $218,426,220 \mathrm{~m} 3$ by 2037 the values were fluctuated from high value to low value according to the recharge variation in terms of time and rate with an interval value of $138,786,870 \mathrm{~m} 3$ by seasonal recharge (summer, winter). This fluctuation is due the seasonal change in the net recharge from agricultural areas during the six months (summer, winter) seasons Figure 14.

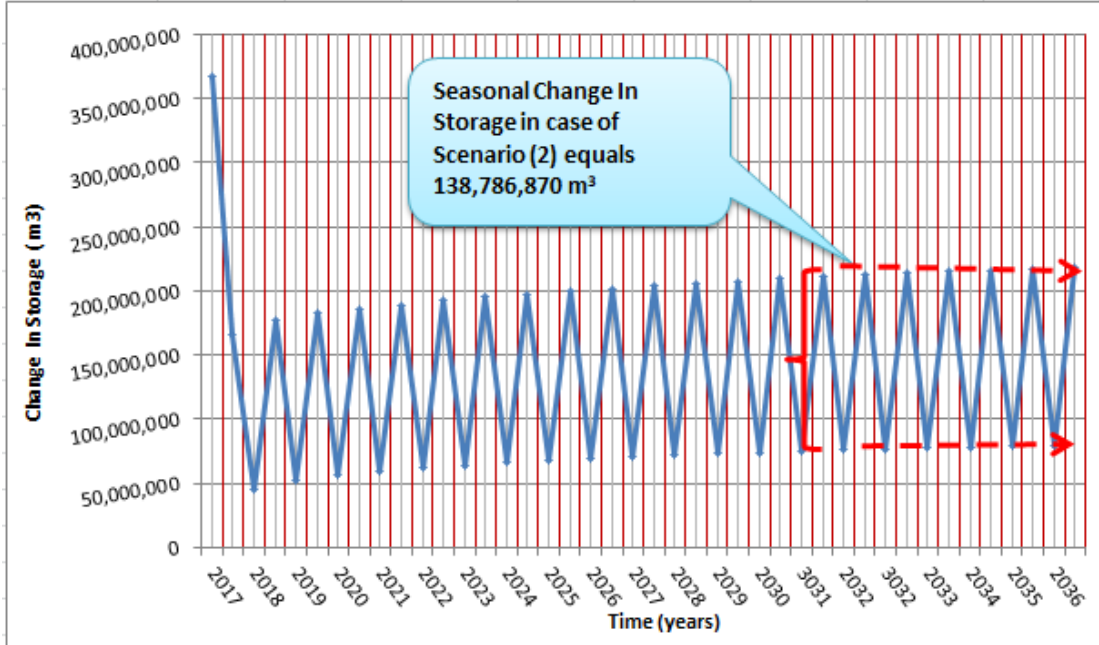

Figure 14. Change in storage (m3) after applied scenario 2 till the year 2037.

Scenario 3: surface water reduction by $20 \%$ against drainage surplus all the year Groundwater Levels

The water levels resulted from this scenario present in Figure 15. it can be noticed that water levels at each of El Mullak and El Shabab were $9.96 \mathrm{~m}$ and $9.87 \mathrm{~m}$ in the year 2016 before applying the reduction, then the levels decreased to $9.80 \mathrm{~m}$ and $9.40 \mathrm{~m}$ at the year 2017 after that the levels were changed to reach $10.1 \mathrm{~m}$ and $8.6 \mathrm{~m}$ after 10 years, $10.4 \mathrm{~m}$ and $9.3 \mathrm{~m}$ respectively after 20 years. The calculated water levels at each of khattara and El Salhiya were $5.49 \mathrm{~m}$ and $6.92 \mathrm{~m}$ in the year 2017, after that the levels slightly increased to reach $5.73 \mathrm{~m}$ and $7.2 \mathrm{~m}$ after 10 years, $5.9 \mathrm{~m}$ and $7.3 \mathrm{~m}$ respectively after 20 years. 


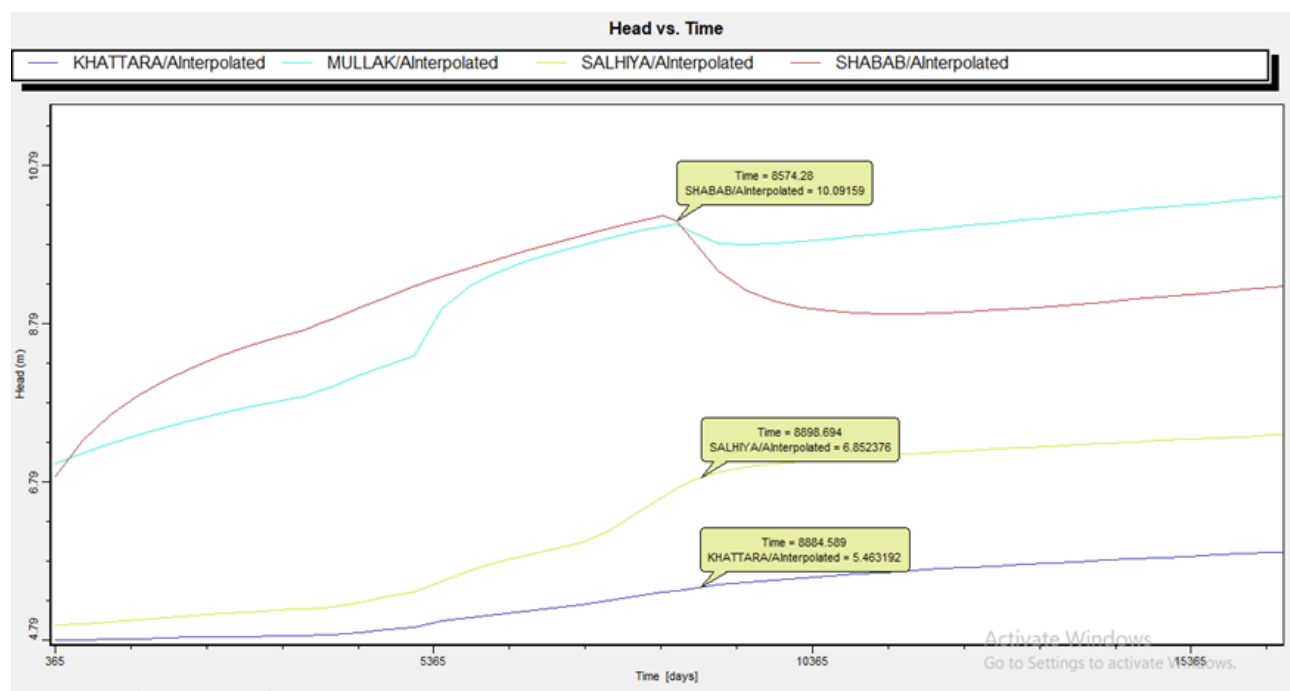

Figure 15. Fluctuation of the groundwater levels after applied scenario 3 till the year 2037.

Change in Storage

In this scenario, the storage in value was decreased from 334,668,500 m3 in 2017 to 249,707,450 m3 in 2018 after one year of the reduction. Then the value of change in storage increased continuously to reach $305,887,885$ $\mathrm{m} 3$ in 2037 as shown in Figure 16.

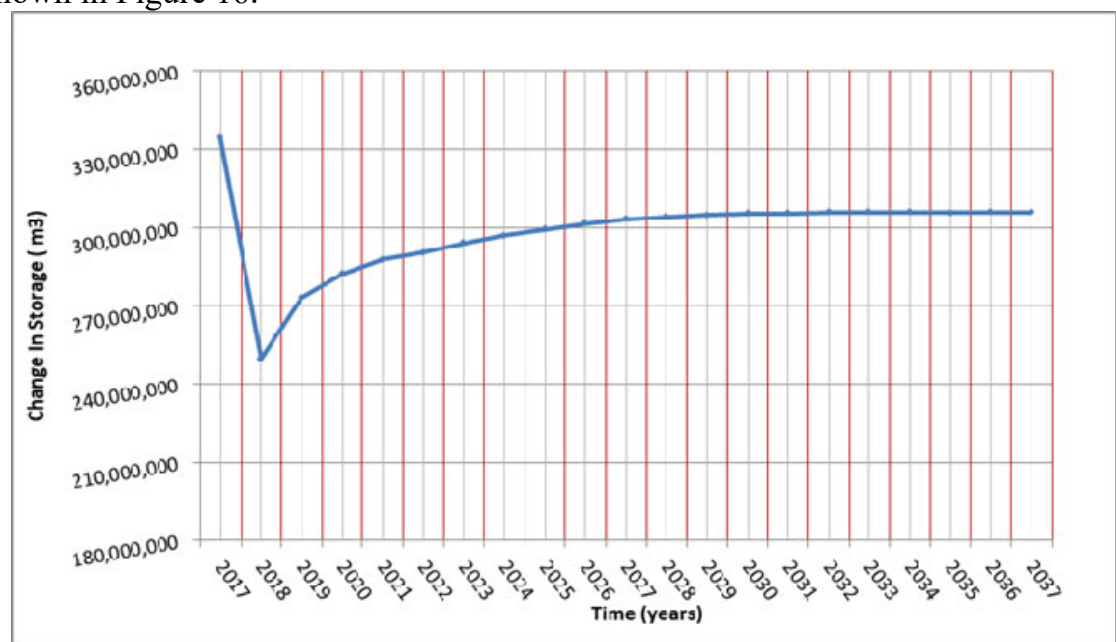

Figure 16. Change in storage (m3) after applied scenario 3 till year 2037

Scenario 4: surface water reduction by $20 \%$ against seasonal drainage surplus for six months (summer, winter). Groundwater Levels

for scenario 4 from the results of water levels at different time step Figure17. It can be observed that the calculated water levels at each of El Mullak and El Shabab were $10.32 \mathrm{~m}$ and $9.88 \mathrm{~m}$ at the year 2016 before applying the reduction then the levels increased to $9.86 \mathrm{~m}$ at El Mullak while dropped to $9.45 \mathrm{~m}$ at the year 2017 . At El Shabab the levels decreased to $9.46 \mathrm{~m}$ in the year 2017. The levels were changed to reach $9.65 \mathrm{~m}$ and $8.51 \mathrm{~m}$ after 10 years, $9.85 \mathrm{~m}$ and $8.5 \mathrm{~m}$ after 20 years at El Mullak and El Shabab respectively. The calculated water levels at each of khattara and El Salhiya were $5.49 \mathrm{~m}$ and $6.92 \mathrm{~m}$ in the year 2017 then the levels changed to reach $5.43 \mathrm{~m}$ and $6.37 \mathrm{~m}$ after 10 years, $5.54 \mathrm{~m}$ and $6.62 \mathrm{~m}$ respectively after 20 years. It can be noticed that there is a fluctuation of the water levels appeared as a result of the seasonal recharge rate. 


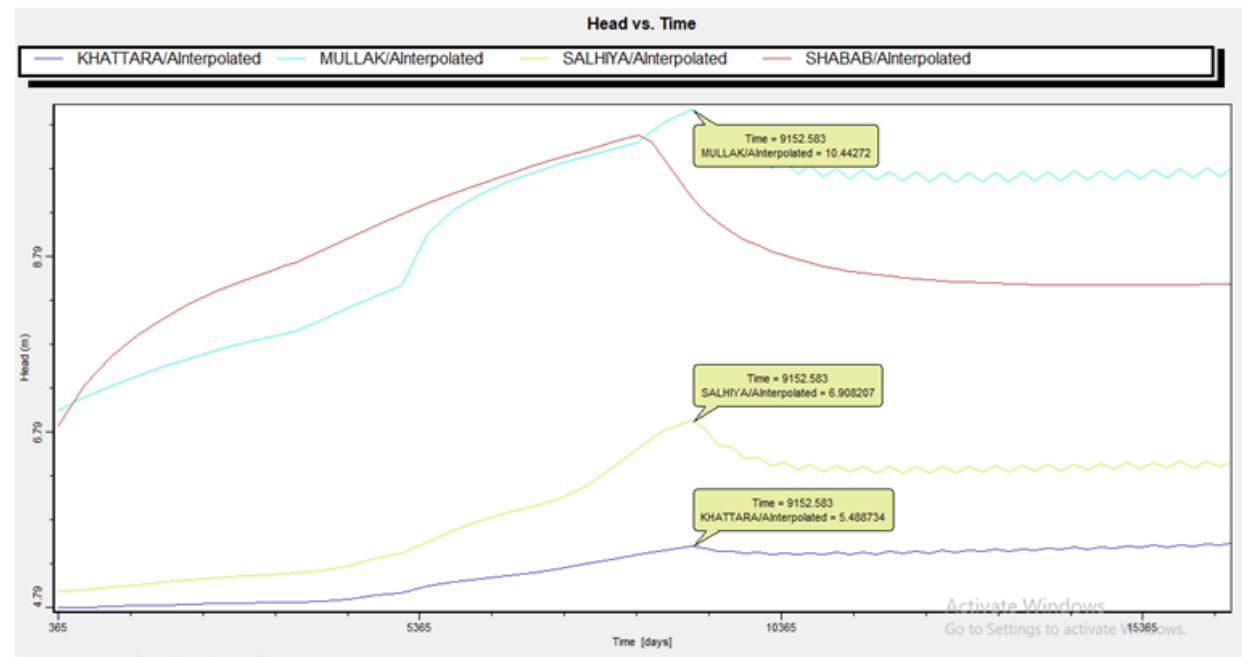

Figure 17. Fluctuation of the groundwater levels after applied scenario 4 till the year 2037 .

Change in Storage

In this scenario, the change in storage value was decreased from $366,361,450 \mathrm{~m} 3$ in 2017 to $3,281,350 \mathrm{~m} 3 \mathrm{in}$ 2018 after one year of the reduction. Then this value increased to 193,946,035 $\mathrm{m} 3$ by 2037 the values were fluctuation from high value to low value according to the recharge variation in terms of time and rate with an interval value of $138,382,085 \mathrm{~m} 3$ by seasonal recharge (summer, winter). This fluctuation is due the seasonal change in the net recharge from agricultural areas during the six months (summer, winter) seasons Figure 18.

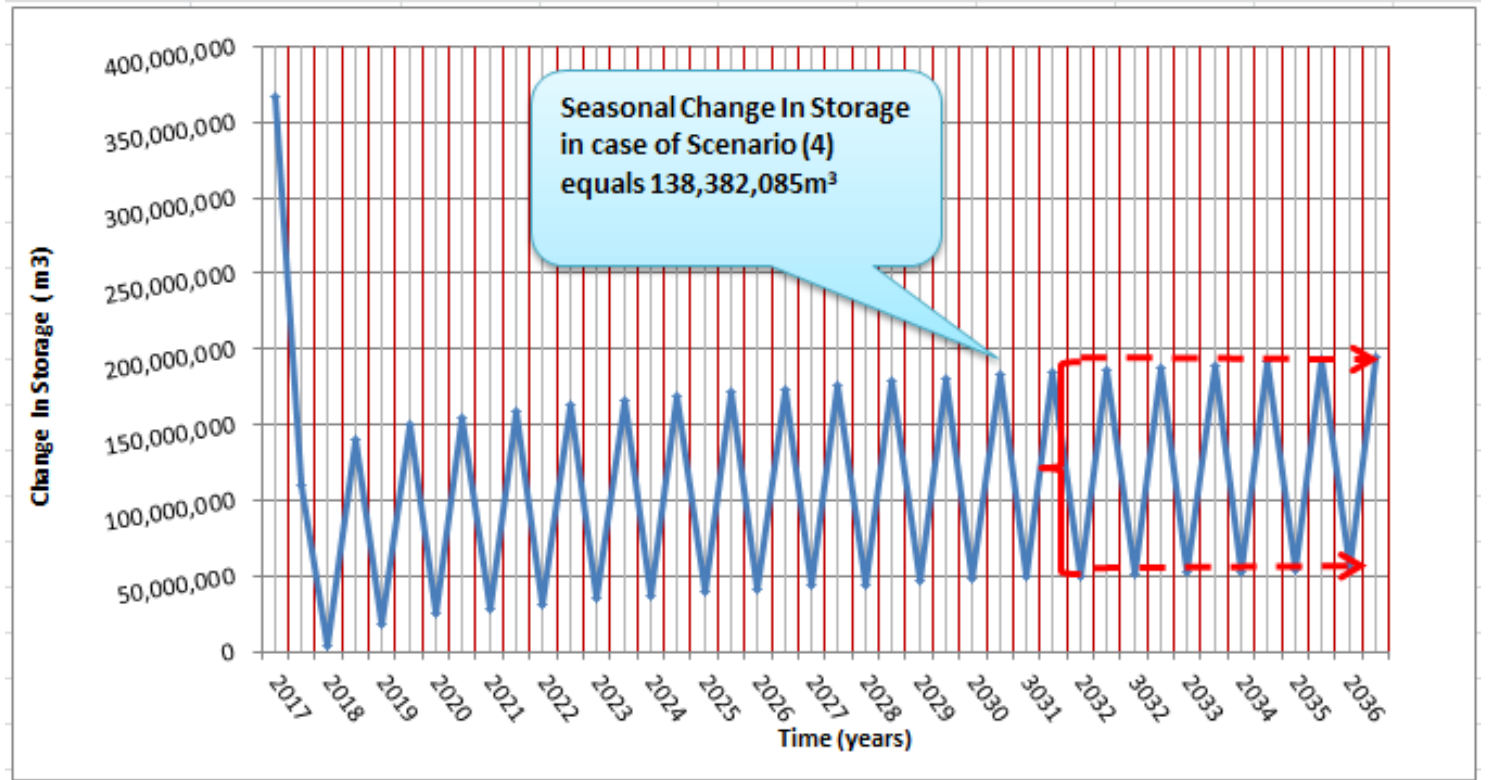

Figure 18. Change in storage (m3) after applied scenario 4 till the year 2037.

\section{6-Conclusion}

Based on the hydrogeological conditions and the results of the regional groundwater flow model, it can be concluded that: In the Eastern Nile Delta, there are various available water resources. The main source of surface water is Nile water. and the main canals and drains (Ismailia canal, El Rayah El Tawfiqy, El Saidiya Canal, Mullak canal, EL Qalubiya drain, Belbis drain, and Bahr EL Baqr drain).

There is a change in the source of irrigation water (additional surface water supply) in some reclamation lands from groundwater (khatara and Ramsis .etc), into surface water. Consequently, the lateral flow from the high reclamation lands increases to the areas located in the transition zone (border between the high lands and low ones). In addition to the leakage from Ismailia Canal led to the rising water table in such areas (adjacent to the Ismailia Canal) causing the waterlogging and salinization problem.

From the analysis of the water balance components from 1992 to 2015 .it can be noticed that the main source for recharging the aquifer represented by the leakage from the surface water system and the recharge from reclamation areas the analysis revealed that the value of net recharge to the aquifer increased from $62 \%$ to $80 \%$ as a result of increasing the agricultural lands during the period 1992 to 2015 .also the extraction of wells 
decreased from $52 \%$ to $51 \%$ as a result of some reclamation areas were transformed from groundwater to surface water and conjunctive use as Ramsis, khattara, and west of khattara.

The analysis of the simulated scenarios revealed that the reduction in the surface water system of the Nile river and main canal had a negative impact on the groundwater levels especially at the reclamation projects located north and south of the Ismailia canal .also the aquifer storage has affected by the surface water reduction but the aquifer storage returned to increase by time the results showed a change and fluctuation in the groundwater levels under the proposed scenarios. While the maximum value of the change in storage was found in scenario 2 in which this value was decreased by $52.9 \%$ between 2017 and 2037 . but in all scenarios, the change in storage of the aquifer still stable and continuously increase, by $36.5 \%$ under scenario 2 and $29 \%$ under scenario 4.

\section{References}

Abdel Salam M., Fekry A., Gaame O., and Hussein M., (2004). Groundwater development strategies for drought (case study on the Nile Delta aquifer system) Proc. 3rd. International Symposium on Geophysics, Tanta (2004): 233-243.

Abdulaziz, A. M. (2007). Applications of remote sensing, GIS, and groundwater flow modeling in evaluating groundwater resources; two case studies: East Nile Delta, Egypt and Gold Valley, California, USA. [Ph.D. thesis]: University of Texas at El Paso, $315 \mathrm{p}$

Abdelhalim, A., Sefelnasr, A., \& Ismail, E. (2020). Response of the interaction between surface water and groundwater to climate change and proposed megastructure. Journal of African Earth Sciences, 162, 103723.

Aziz, S.A., Zeleňáková, M., Mésároš, P., Purcz, P., Abd-Elhamid, H. (2019) “Assessing the Potential Impacts of the Grand Ethiopian Renaissance Dam on Water Resources and Soil Salinity in the Nile Delta, Egypt", Sustainability, 11, 7050 .

Dahab, K. A., Omran, A. A., Abdalall, G. Z., \&Alkilany, S. M. (2009). Hydrochemical studies of the quaternary groundwater aquifer in El Salhiya area and its vicinities, East Nile Delta, Egypt. Journal of the Faculty of Science Menoufia University, XXIII, 171-193.

Elimy, E. A., Hassan, A. A., Omar, M. A., Nasser, G. A. E., \& Riad, P. H. (2020). Land Use/Land Cover Change Detection Analysis for Eastern Nile Delta Fringes, Egypt. Journal of Environment and Earth Science, Vol.10, No.10, 2020

Eltarabily, M. G. A., \& Negm, A. M. (2017). Groundwater management for sustainable development east of the nile delta aquifer. In Groundwater in the Nile Delta (pp. 687-708). Springer, Cham.

El-Rawy, M., Moghazy, H. E., \& Eltarabily, M. G. (2021). Impacts of decreasing Nile flow on the Nile Valley aquifer in El-Minia Governorate, Egypt. Alexandria Engineering Journal, 60(2), 2179-2192.

Harbaugh A.W, Banta E.R., Hill M.C. and McDonald, M.G. (2000), "MODFLOW-2000, The U.S. geological survey modular ground-water model-user guide to modularization concepts and the ground-water flow process", United States Geological Survey Open-File Report 00- 92.

McDonald, M.G., and Harbaugh, A.W. (1988). A modular, three-dimensional, finite-difference ground-water flow model: U.S. Geological Survey Techniques of Water-Resources Investigations, Book 6, Chap. A1, 586 $\mathrm{p}$.

RIGW/IWACO, (1988). Development and Management of Groundwater Resources in the Nile Valley and Delta, TN70.120-88-07, Research Institute for Groundwater, Kanater EL Khairia, Cairo Egypt .

RIGW/IWACO, (1992), "Hydrogeological Map of the Nile Delta scale 1: 500,000”, Ministry of Irrigation, Water Research Center, Research Institute for Groundwater, RIGW, Egypt.

Link 1: website https://earthexplorer.usgs.gov/with spatial resolution 